\title{
Sporządzanie ekspertyz i opinii technicznych w oparciu o badania wizualne luf artyleryjskich
}

\author{
Technical expertise and opinion \\ based on visual testing artillery barrels
}

\section{Streszczenie}

W artykule dokonano charakterystyki wybranych problemów badań wizualnych luf artyleryjskich, które stanowią źródło podstawowych informacji niezbędnych dla podjęcia decyzji dotyczących badanych luf artyleryjskich lub decyzji diagnostycznych (opinia techniczna), związanych z ich dalszą eksploatacją. Badania wizualne należą do grupy badań nieniszczących pozwalających na szybkie, dokładne i jednoznaczne określenie stanu technicznego wewnętrznych przestrzeni luf armat artyleryjskich. Zaprezentowano tez przykład rozwiązań firmy Olympus współpracującej z wojskiem, w których oferowane rozwiązania powstają $\mathrm{w}$ oparciu o najnowsze rozwiązania technologiczne i spełniające wysokie wymagania wojskowe. Badania diagnostyczne zakończone sporządzaniem ekspertyzy i opinii technicznej w oparciu o badania wizualne luf artyleryjskich zajmują istotną pozycję w procesie bezpieczeństwa eksploatacji.

Słowa kluczowe: bezpieczeństwo eksploatacji, lufa artyleryjska, badania wizualne

\section{Abstract}

The article presents the characteristics of selected problems of visual testing artillery barrels, which are a source of basic information necessary to make decisions regarding the respondents barrels of artillery or diagnostic decisions (technical opinion) associated with their further exploitation. Visual Testing belong to the group of NDT (Non-Destructive Testing) enabling fast, accurate and unambiguous definition of the technical condition of the interior spaces artillery cannon barrels. Also presents example solutions Olympus cooperating with the army. which offered solutions are based on the latest technology and meet demanding military specifications. Investigations completed drafting expertise and technical opinion based by visual testing artillery barrels occupy an important position in the process of safety in exploitation.

Keywords: operational safety, barrel artillery, visual testing

\section{Wstęp}

Współczesne armaty posiadają na swoim wyposażeniu coraz doskonalsze lufy artyleryjskie, pomimo tego, w praktyce eksploatacyjnej znane są przypadki poważnych ich uszkodzeń, których pierwotne przyczyny nie zostały wykryte w odpowiednim czasie. Trudności rozpoznawania uszkodzeń luf artyleryjskich na podstawie zmian wartości poszczególnych parametrów charakteryzujących stan techniczny, związane są z niewłaściwą interpretacją symptomów powstałego defektu. Często są one identyfikowane, jako symptomy naturalnego procesu starzenia lub zużycia poszczególnych elementów uzbrojenia artyleryjskiego zdeterminowane czasem jego eksploatacji. Zewnętrzne objawy w takich przypadkach są zazwyczaj zbieżne i trudne do jednoznacznego określenia. W takich przypadkach jedyną możliwość uzyskania arbitralnej diagnozy o stanie technicznym armat tj., luf artyleryjskich zapewnia wzier- nikowanie jego przestrzeni wewnętrznych z wykorzystaniem endoskopów. W sposób bezinwazyjny, bardzo szybki, a co najważniejsze jednoznaczny rozwiane zostają wątpliwości nurtujące eksploatatora.

Również nieeksploatowane wyroby obronne, w tym armaty znajdujące się w magazynach i składach, przechowywane przez lata, mogą też być później instalowane na okrętach, w każdej chwili muszą być w stanie pełnej sprawności bojowej.

Aby uzbrojenie artyleryjskie mogło wypełnić stojące przed nim zadanie, powinno być w każdej chwili w pełnej sprawności, wszystkie części, urządzenia, mechanizmy i układy powinny być prawidłowo zakonserwowane, tj. np. nasmarowane zabezpieczone przed korozją. Troskliwy stosunek do uzbrojenia jest dowodem wysokiej kultury technicznej i dyscypliny żołnierzy.

Mgr inż. Szymon Kubisiak - Olympus Polska Sp. z o.o, mgr inż. Mirosław Chmieliński, dr inż. Artur Cywiński - Akademia Marynarki Wojennej. 


\section{Charakterystyka eksploatacji luf artyleryjskich}

Prawidłowa ocena stanu technicznego luf armatnich wymaga doświadczenia i wiąże się z dużą odpowiedzialnością, lecz prawidłowo wykonana może uchronić ww. sprzęt przed ostateczną utratą własności, zminimalizować koszty, a w szczególności zapobiec nie rzadko śmiertelnym wypadkom. Umiejscowienie diagnostyki technicznej wyrobów obronnych w problematyce monitorowania i zarządzania w czasie realizacji m.in. projektów badawczo-rozwojowych, wskazuje na jej miejsce i zadania, a racjonalne wprowadzanie osiągnięć nowoczesnych technologii diagnostycznych zapewnia efektywność ekonomiczną ich funkcjonowania.

Badania nieniszczące, w omawianym przypadku to badania wizualne metodą endoskopową, pozwalają na szybką i wnikliwą ocenę stanu technicznego luf artyleryjskich, bez konieczności częściowego demontażu ww. sprzętu, a służą wykryciu przyczyn awarii lub uszkodzenia sprzętu, jak również wyeliminowaniu przyczyn niesprawności, dla zapewnienia bezpiecznej eksploatacji uzbrojenia [4]. Przy opracowywaniu prognoz diagnostycznych uzbrojenia artyleryjskiego, należy uwzględniać dane o prawidłowości rozwoju procesów kontrolowanych i ich uwarunkowaniach rozwojowych, a także możliwych dodatkowych czynnikach wpływających na ich przebieg. Podstawowym założeniem badań nieniszczących jest dokonanie oceny stanu badanego obiektu bez dokonywania ingerencji w jego budowę i wzajemne połączenia, a tego typu diagnostyka jest nauką zajmującą się badaniem stanu obiektów za pomocą metod, które można określić jako bezinwazyjne. Nazwa taka przyjęła się powszechnie w medycynie i dobrze oddaje istotę stosowanych metod badawczych: badanie nie powoduje zniszczenia obiektu, a jego stan, pomimo przeprowadzenia badania, nie zmienia się.

W trakcie eksploatacji lufy artyleryjskich ulegają zużyciu. Zużycie to jest wynikiem oddziaływania gazów prochowych o wysokiej temperaturze, tarcia pocisku o ścianki oraz chemicznych reakcji zachodzących pomiędzy aktywnymi produktami spalania prochu i materiału lufy.

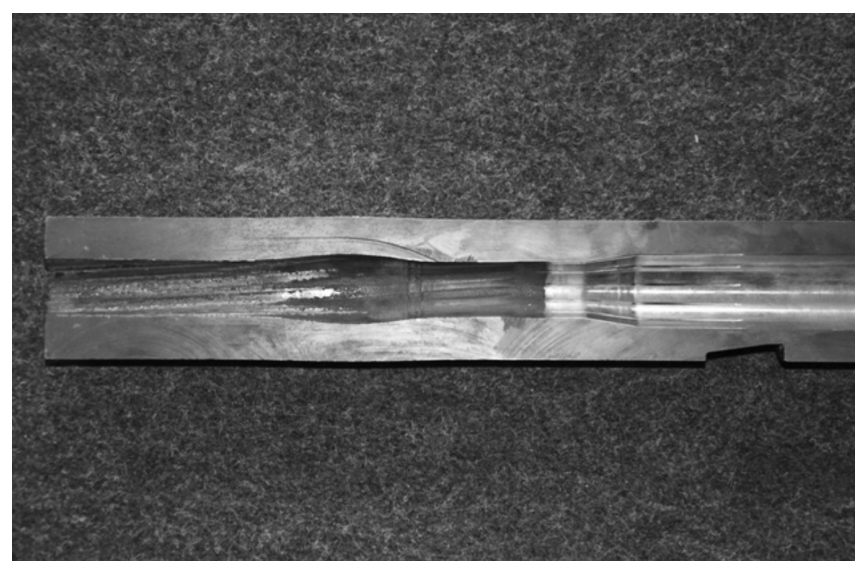

Rys. 1. Przykład uszkodzonej 23 mm lufy ZU-23-2M. Źródło: Opracowanie własne

Fig. 1. The example of damaged $23 \mathrm{~mm}$ barrel of ZU-23-2M. Reference: private elaboration

Efektem działania powyższych czynników jest powstawanie ubytków materiału, pęknięć i szczelin oraz odprysków powłoki ochronnej (jeżeli jest zastosowana) w przewodzie lufy. Intensywność i charakter tych zjawisk jest zależny od kalibru działa, używanych typów pocisków i rodzaju stosowanych materiałów miotających.
Z punktu widzenia użytkownika istotne jest pogorszenie własności balistycznych działa wskutek zachodzących zmian erozyjnych w przewodzie lufy oraz niebezpieczeństwo rozerwania lufy przy przekroczeniu granicznej wytrzymałości zmęczeniowej materiału. Czynnikami wpływającymi na zużycie luf artyleryjskich są gazy powybuchowe, wchodzące $w$ reakcje z materiałem lufy [7].

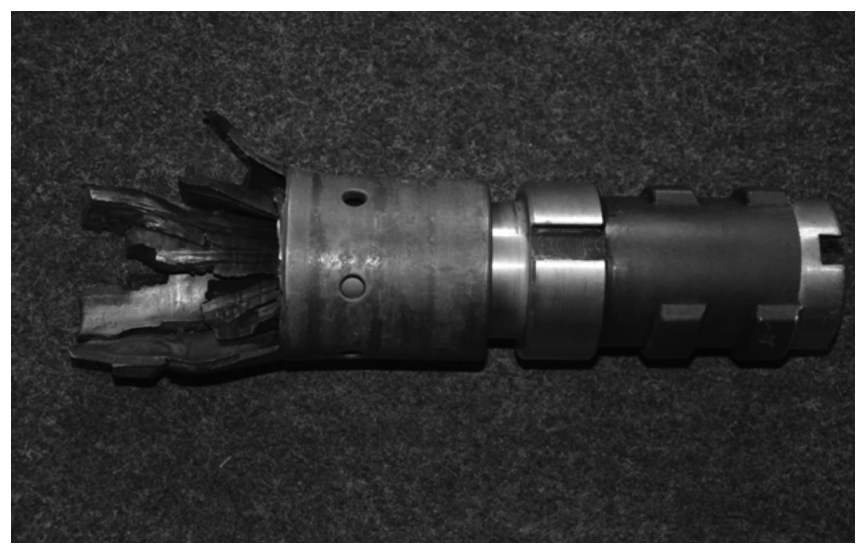

Rys. 2. Przykład uszkodzenia 30mm lufy Ak-230. Źródło: Opracowanie własne

Fig. 2. The example of damage $30 \mathrm{~mm}$ barrel of Ak-230. Reference: private elaboration

Największy wpływ na erozję chemiczną lufy ma dwutlenek węgla, następnie tlenek węgla, woda i wodór. Natomiast azot posiada własności ochronne. Wysoka temperatura spalania prochów wpływa w różnych aspektach na proces erozji. Nagrzewanie się ścianek lufy powoduje zmiękczanie materiału i wrażliwość na mechaniczne ścieranie. W przewodach luf pokrytych warstwą ochronną np. chromu, powstają naprężenia powodujące odpryski i wykruszenia. Wysoka temperatura wpływa także na zwiększenie i przyśpieszenie zachodzących reakcji chemicznych powodujących erozję chemiczną przemiany fazowe w stali. Temperatura ścianek lufy wprost zależy od temperatury spalania się prochu. Aktualnie do produkcji amunicji artyleryjskiej stosowane są prochy nitrocelulozowe (tzw. jednobazowe), prochy nitroglicerynowe (tzw. dwubazowe) oraz wieloskładnikowe (najczęściej trój-bazowe, nitroguanidynowe). Najbardziej energetyczne prochy nitroglicerynowe, o największej wartości siły prochu, są stosowane $w$ ładunkach miotających naboi z podkalibrowymi pociskami przeciwpancernymi.

Erozja mechaniczna lufy spowodowana tarciem części prowadzących pocisku o ścianki lufy, przepływem gazów przez szczeliny pomiędzy pociskiem i ściankami zależy od konstrukcji pocisku i w zasadzie jest stała jeżeli nie uwzględniamy wpływu czynników chemicznych i temperaturowych.

Właśnie te dwa czynniki mają bowiem decydujący wpływ także na zużycie mechaniczne lufy. Dotyczy to zarówno tzw. żywotności zmęczeniowej, która określa liczbę strzałów dopuszczalną z uwagi na wytrzymałość lufy oraz tzw. żywotności balistycznej związanej ze zużywaniem się lufy wskutek erozji przewodu, która powoduje spadek własności balistycznych działa jak zwiększenie rozrzutu, spadek prędkości początkowej pocisków i pogorszenie się stabilizacji pocisków (głównie w działach gwintowanych) [8].

Kryterium wycofywania luf z eksploatacji zależy od typu działa, technologii wykonania przewodu (np. pokrycie chromem) oraz rodzaju i konstrukcji używanych naboi.

W lufach bez pokrycia najczęściej obserwuje się powiększenie średnicy wewnętrznej (największe w okolicy stożka 
przejściowego, stopniowo malejące w kierunku wylotu).

Troska o sprzęt artyleryjskiego uzbrojenia morskiego, w tym m.in. działania antykorozyjne polegają na codziennej pielęgnacji i czyszczeniu, przeglądach i naprawach profilaktycznych oraz przygotowaniu do bojowego użycia, przegląd ten i zespół czynności składających się na jego realizacją nazywana jest na okręcie codziennym obracaniem mechanizmów. Do prac tych wykorzystywane są tylko odpowiednie narzędzia i przyrządy, właściwe smary i farby oraz inne materiały konserwacyjne. Morskie uzbrojenie artyleryjskie powinno być zawsze czyste, nie może być na nim pyłu, wilgoci, osadu prochu i rdzy. Szczelne "okrycie" armaty szczególnie w warunkach morskich, ogranicza w znacznym stopniu korodowanie powierzchni pod wpływem agresywnie korozyjnego środowiska, jakim jest woda i atmosfera morska.

Utrzymanie uzbrojenia artyleryjskiego w sprawności technicznej i w stanie, który gwarantuje długotrwałą eksploatację bez obawy korozji, jest zawsze stałą troską całego składu osobowego okrętu [1]. Jednak w procesie długotrwałej eksploatacji morskiego uzbrojenia artyleryjskiego następuje naturalne zniszczenie powłok ochronnych i zanieczyszczenie smarów znajdujących się w mechanizmach, co może powodować powstanie warunków sprzyjających inicjacji wzmożonych procesów korozyjnych. Codzienne czyszczenie staje się wtedy niewystarczające i należy zastosować tzw. przegląd i naprawę profilaktyczną, w czasie których dokonuje się prawie pełnego demontażu poszczególnych zespołów armaty. Przeprowadza się czyszczenie i mycie mechanizmów, wymianę smarów i płynów, ich filtrowanie, wymianę zużytych części, a także usuwanie drobnych niesprawności. Codzienne zabiegi pielęgnacyjne wykonuje się zwykle na okręcie, zaś przegląd profilaktyczny automatów artyleryjskich odbywa się w warsztatach Baz Morskich lub wydziałach uzbrojenia zakładów produkcyjnych.

Przeglądy profilaktyczne zbrojenia artyleryjskiego znajdującego się na okrętach przeprowadza się raz do roku. Do niedawna przeglądy te robiono dwa razy w roku, gdyż wymieniano wtedy smary - wiosną na letni, a jesienią na zimowy. Wprowadzenie smarów zimowo-letnich wyeliminowało konieczność przeprowadzania dwóch przeglądów w ciągu roku. Obecnie przeglądy profilaktyczne przeprowadza się niezależnie od pory roku, bardziej równomiernie, spokojniej, a co za tym idzie, dokładniej [3].

Rozróżnia się cztery zasadnicze procesy, które określają charakter i wielkość zużywania się nie tylko korozyjnego luf działowych:

1. Działanie termiczne gazów prochowych na powierzchnie materiału z którego wylano lufę w czasie wystrzału.

2. Oddziaływanie chemiczne nagrzanych do wysokiej temperatury gazów prochowych z metaliczną powierzchnią lufy.

3. Mechaniczne niszczenie powierzchni ścianek przewodu lufy przez poruszający się tam pocisk i zmniejszane są ciśnienie gazów.

4. Erozyjne działanie szybko poruszających się w stosunku do przewodu lufy nagrzanych gazów prochowych.

W zależności od konstrukcji i charakterystyk balistycznych lufy, wielkości ładunku, gatunku prochu i środków inicjujących, a także od ilości oddanych wystrzałów i od stopnia zużycia lufy - jeden z wymienionych procesów jest przeważający, a pozostałe, chociaż zachodzą równolegle, to jednak oddziaływanie ich jest drugorzędne. Wszystkie te procesy zachodzą w lufie w przeciągu jej „życia balistycznego", lecz w różnych okresach rola ich jest niejednakowa. Zmiana przekroju głównego lufy powodowana przez takie pęknięcia lub wżery może być przyczyną „rozdęcia” lufy, rysunek 3.

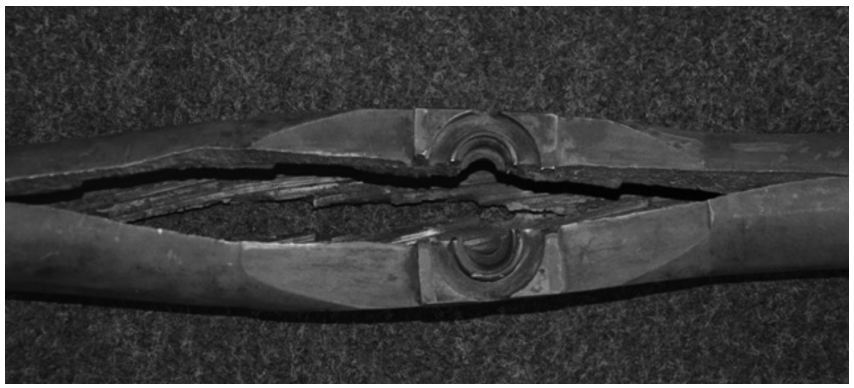

Rys. 3. Przykład rozdęcia 30mm lufy Ak-630. Źródło: Opracowanie własne

Fig. 3. The example of distension $30 \mathrm{~mm}$ barrel of Ak-630. Reference: private elaboration

Świadectwem początku procesu zużywania się przewodu lufy jest pojawienie się siatki wypaleń [4]. Siatka wypaleń jest to bardziej lub mniej rozwinięta siatka mikropęknięć powierzchniowych, które pogłębiają i rozszerzają się wraz ze wzrostem ilości wystrzałów. Te mikropęknięcia - jako skokowa niejednorodność są również źródłem korozji wżerowej - podczas długoletniej eksploatacji łączą się i tworzą niebezpieczne pęknięcia. Siatka pęknięć najwcześniej powstaje i jest najbardziej wyraźna w strefie od stożka przejściowego lufy do miejsca, gdzie działa największe ciśnienie gazów prochowych. W kierunku do wylotu lufy siatka pęknięć jest coraz mniejsza i przy samym wylocie prawie niewidoczna.

\section{Wizualna diagnostyka techniczna lufy}

Podstawowym założeniem diagnostyki jest dokonanie oceny stanu badanego obiektu bez dokonywania ingerencji w jego budowę i wzajemne połączenia. Diagnostyka jest więc nauką zajmującą się badaniem stanu obiektów za pomocą metod, które można określić jako bezinwazyjne. Nazwa taka przyjęła się powszechnie w medycynie i dobrze oddaje istotę stosowanych metod badawczych: badanie nie powoduje zniszczenia obiektu, a jego stan, pomimo przeprowadzenia badania, nie zmienia się. Badania diagnostyczne stosowane są również w technice wszędzie tam, gdzie nie jest możliwe przeprowadzenie demontażu elementów lub podzespołów, gdzie naruszenie struktury zespołu może prowadzić np. do przedwczesnego zużycia współpracujących części i wreszcie wtedy, gdy zdemontowanie części i przeprowadzenie tzw. rozbiórki warsztatowej i próba oceny stanu współpracujących części może okazać się zbyt kosztowna i pracochłonna, a efekt daleko odbiegający od oczekiwanego [2].

Umiejscowienie diagnostyki technicznej uzbrojenia w monitorowania i zarządzania w czasie realizacji projektów badawczo-rozwojowych, wskazuje na jej miejsce i zadania, a racjonalne wprowadzanie osiągnięć nowoczesnych technologii diagnostycznych zapewnia efektywność ekonomiczną ich funkcjonowania.

Przy opracowywaniu prognoz diagnostycznych uzbrojenia, należy uwzględniać dane o prawidłowości rozwoju procesów kontrolowanych i ich uwarunkowaniach rozwojowych, a także możliwych dodatkowych czynnikach wpływających na ich przebieg.

Podstawowym założeniem diagnostyki jest dokonanie oceny stanu badanego obiektu bez dokonywania ingerencji w jego budowę i wzajemne połączenia. Diagnostyka jest więc nauką zajmującą się badaniem stanu obiektów za pomocą metod, które można określić jako bezinwazyjne. Nazwa taka przyjęła się powszechnie w medycynie i dobrze oddaje istotę stosowanych metod badawczych: badanie 
nie powoduje zniszczenia obiektu, a jego stan, pomimo przeprowadzenia badania, nie zmienia się.

Badania diagnostyczne stosowane są również w technice; wszędzie tam, gdzie nie jest możliwe przeprowadzenie demontażu elementów lub podzespołów, gdzie naruszenie struktury zespołu może prowadzić np. do przedwczesnego zużycia współpracujących części i wreszcie wtedy, gdy zdemontowanie części i przeprowadzenie tzw. rozbiórki warsztatowej i próba oceny stanu współpracujących części może okazać się zbyt kosztowna i pracochłonna, a efekt daleko odbiegający od oczekiwanego [5].

Z doświadczeń eksploatatorów i użytkowników uzbrojenia morskiego wynika też, że problemy związane z zabezpieczeniem antykorozyjnym są bardzo powszechne i występują we wszystkich branżach przemysłowych, niezależnie od wielkości i stopnia złożoności zakładów.

W ostatnich latach można zaobserwować w wojsku tendencje do ograniczania kosztów eksploatacji uzbrojenia, przy jednoczesnej poprawie jego niezawodności i dyspozycyjności. Wynika to z czysto ekonomicznego podejścia. Rosnące wymagania rynkowe i konkurencja zmuszają do poszukiwania nowych rozwiązań. Następuje przekładanie tych oczekiwań na dostawców uzbrojenia morskiego tj. jego materiałów, urządzeń i usług, nakłaniając ich do opracowywania nowych racjonalnych ekonomicznie i niezawodnych rozwiązań technologicznych [3].

Nie eksploatowane armaty znajdujące się w magazynach i składach, a przechowywane przez lata, a mogą być później instalowane na okrętach, w każdej chwili muszą być w stanie pełnej sprawności bojowej. Aby morskie uzbrojenie artyleryjskie mogło wypełnić stojące przed nim zadanie, powinno być w każdej chwili w pełnej sprawności, wszystkie części, urządzenia, mechanizmy i układy powinny być prawidłowo zakonserwowane, tj. nasmarowane lub pomalowane stosunek zabezpieczone. Troskliwy stosunek do uzbrojenia morskiego jest dowodem wysokiej kultury technicznej i dyscypliny załogi okrętu.

Prawidłowa ocena stanu technicznego uzbrojenia artyleryjskiego wymaga doświadczenia i wiąże się z dużą odpowiedzialnością, lecz prawidłowo wykonana może uchronić sprzęt przed ostateczną utratą własności, zminimalizować koszty, a w szczególności zapobiec nie rzadko śmiertelnym wypadkom.

Badania endoskopowe pozwalają na szybką i wnikliwszą ocenę stanu technicznego uzbrojenia bez konieczności częściowego demontażu w/w sprzętu, jako badania nieniszczące służą wykryciu przyczyn awarii lub uszkodzenia sprzętu, jak również wyeliminowaniu przyczyn niesprawności, dla zapewnienia bezpiecznej eksploatacji uzbrojenia [4].

Jednym z ważniejszych sposobów oceny stanu lufy artyleryjskiej jest skontrolowanie jej wyglądu wzrokowo, jednak w wielu przypadkach taka ocena jest bardzo utrudniona ze względu na jej położenie i możliwość odpowiedniego ustawienia oka. W wielu przypadkach obejrzenie lufy dokładnie gołym okiem staje się bez demontażu po prostu niemożliwe.

Badania wizualne to najstarsza i najbardziej rozpowszechniona metoda kontroli. Badania takie przeprowadza się okiem nieuzbrojonym, bądź z wykorzystaniem specjalistycznych przyrządów optycznych. Dysponując prostymi środkami, umożliwiającymi zajrzenie w te trudno dostępne miejsca, można znacząco zmienić jakość wykonywanego badania. Metody te, niezależnie od ich wysokiej przydatności i wiarygodności, umożliwiają jednak ocenę stanu elementów w sposób pośredni i tylko bezpośrednia - wzrokowa ocena wyglądu elementów da rozstrzygnięcie wątpliwości [6].

Dynamiczny rozwój metod diagnostycznych wykorzystują- cych osiągnięcia wielu dziedzin nauki, doprowadził do wielu oryginalnych osiągnięć w dziedzinie diagnostyki technicznej. Obecnie występuje cały wachlarz zupełnie nowych możliwości w diagnozowaniu urządzeń technicznych, w tym również w uzbrojeniu okrętowym i sprzęcie wojskowym [2].

W związku z powyższym artykuł ma na celu zasygnalizowanie możliwości wykorzystania badań endoskopowych w ocenie stanu technicznego luf artyleryjskich.

\section{Charakterystyka oraz warunki badań wizualnych luf artyleryjskich w AMW}

W eksploatacji uzbrojenia Marynarki Wojennej RP coraz powszechniej są już wykorzystywane nowe metody badań diagnostycznych, a w szczególności badania endoskopowe. Nieinwazyjne metody diagnostyczne pozwalają na szybkie i dokładne ustalenie przydatności uzbrojenia morskiego do dalszej eksploatacji, podczas wykonywania jego obsługi. Szczególnie dużą przydatność mogą wykazywać w trudno dostępnych miejscach np. w przypadku, gdy demontaż elementu uzbrojenia jest utrudniony i czasochłonny. Badania nieniszczące uzbrojenia morskiego można wykonać w celu określenia aktualnego stanu technicznego lub wykrycia przyczyn awarii lub uszkodzenia sprzętu, jak również w celu wyeliminowania przyczyn niesprawności, dla zapewnienia bezpiecznej eksploatacji uzbrojenia. Właściwe przygotowanie powierzchni wewnętrzne luf armat morskich do badań polega na usunięciu zanieczyszczeń, smarów, produktów korozji, itp. w taki sposób, aby nie została naruszona pierwotna postać tej powierzchni lub przynajmniej nie zostały zamaskowane (zakryte) takie wady powierzchniowe, które powinny być wykryte w czasie badań.

W Akademii Marynarki Wojennej w Gdyni w Pracowni Broni Rakietowej i Artylerii, pod koniec 2013 roku uruchomiono stanowisko szkolno-badawcze przeznaczone do prowadzenia badań nieniszczących luf armat morskich metodą wizualną za pomocą endoskopowego badania powierzchni wewnętrznych luf. Stanowisko szkolno-badawcze do badań luf armat morskich, wyposażone zostało w urządzenie diagnostyczne do oceny ich stanu technicznego za pomocą wideoskopu oraz urządzenie przeznaczone do czyszczenia przewodu lufy oraz komory nabojowej, jak również narzędzia i materiały do obsługi automatów artyleryjskich oraz urządzenia do rejestracji, archiwizacji i wizualizacji badań luf armat morskich.

Zastosowane rozwiązanie umożliwia nagrywanie obrazów widocznych podczas badań przewodów luf armat morskich oraz ich rejestrowanie. Urządzenie do sprawdzenia stanu technicznego i stopnia zużycia umożliwia dokonanie sprawdzenia powierzchni wewnętrznej lufy o średnicy (kalibrze): $23,30,35,57,76$ i $76,2 \mathrm{~mm}$, a spełnia następujące funkcje, wymagania i możliwości:

- badania wnętrza lufy z określeniem lokalizacji oraz wielkości wady,

- analizowanie, dokumentowanie i archiwizowanie defektów lufy,

- bezpieczne przenoszenie i przewożenie przyrządu (umieszczenie przyrządu i jego elementów w pojemniku transportowym),

- obraz "na żywo" przedstawiony na monitorze pozwala na dokładny widok ścian lufy wewnątrz, umożliwiając szybką diagnozę wstępną,

- urządzenie umożliwia pełny podgląd uszkodzeń,

- umożliwia pomiar interaktywny z powłoką wielokrotną i funkcjami adnotacyjnymi, (skala, tekst, data, itp.), 
- umożliwia zapisywanie i archiwizowanie wyników pomiarów,

- umożliwia porównywanie obrazów archiwalnych i „na żywo".

Dodatkowo w zestaw stanowiska badawczego do endoskopowej diagnostyki luf armatnich wchodzi analizator pomiarowy - zestaw komputerowy z oprogramowaniem do pomiarów i obróbki obrazów, z możliwością zarządzania wydrukiem protokołów i raportów oraz przesyłania wyników do urządzeń komunikacyjnych w trybie on-line poprzez USB i urządzenie do wizualizacji wyników pomiarów.

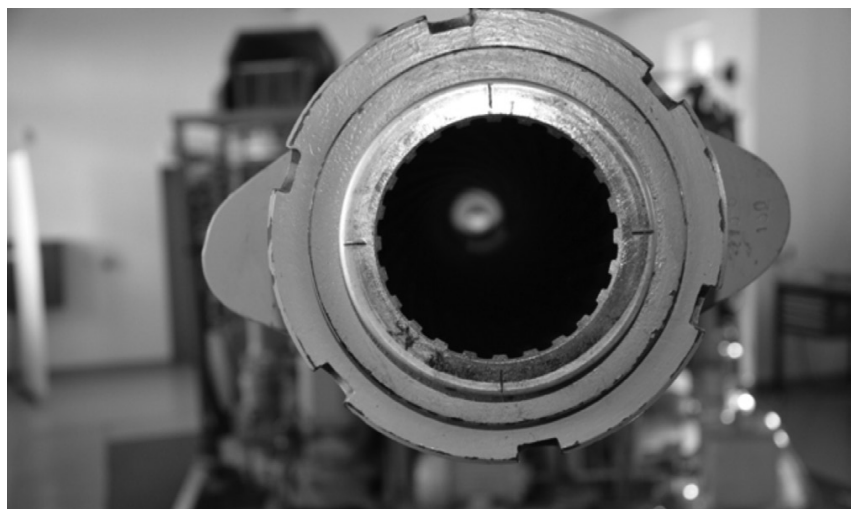

Rys. 4. Przygotowana lufa 76,2mm AK-176 do badań. Źródło: Opracowanie własne

Fig. 4. The prepared barrel of $76,2 \mathrm{~mm}$ of AK-176 for inspection. Reference: private elaboration

Podczas badania ocenie podlegają w szczególności:

- pęknięcia, rysy oraz ubytki materiału;

- intensywność procesów zanieczyszczenia i zużycia przewodu lufy;

- lokalne ogniwa korozji oraz erozji powierzchniowej lufy. Badanie pozwalają na szybkie i dokładne ustalenie przydatności luf artyleryjskich do eksploatacji.

Badania wizualne luf artyleryjskich wykonywane są w celu określenia aktualnego ich stanu technicznego lub wykrycia przyczyn zużycia lub uszkodzenia luf, jak również w celu wyeliminowania przyczyn niesprawności, dla zapewnienia bezpiecznej eksploatacji luf armat morskich.

Do badań wykorzystywany jest zestaw diagnostyczny wideoskop IPLEX LX rysunek 5. Przeprowadzenie badań "diagnostyki endoskopowej luf armat morskich" mogą wykonać:

- osoby posiadający wykształcenie techniczne oraz doświadczenie w pracy zawodowej min. 3 lata z uzbrojeniem;

- żołnierze zawodowi lub rezerwy, którzy przeszli szkolenia w zakresie bezpiecznego posługiwania się uzbrojeniem artyleryjskim zgodnie z przepisami i regulaminami;

- posiadający doświadczenie w prowadzeniu badań endoskopowych;

- posiadający wiedzę z zakresu badań diagnostycznych uzbrojenia;

- zostały zapoznane z warunkami bezpieczeństwa wykonywania badania oraz odpowiedzialnością prawną.

Zastosowane rozwiązanie powinno być wykonane z wykorzystaniem metody nagrywania video prowadzonych badań oraz rejestrowania zdjęć poszczególnych przewodów luf armat morskich.

Badania za pomocą wideoskopu prowadzone są w różnych warunkach, często poza pomieszczeniami, na otwartym powietrzu. Wymagane jest, by odbywały się w atmosferze wolnej od kurzu, brudu i opadów atmosferycznych. Wyklucza się obecność gazów agresywnych ujemnie wpływających na układy optyczne oraz palnych i wybuchowych.

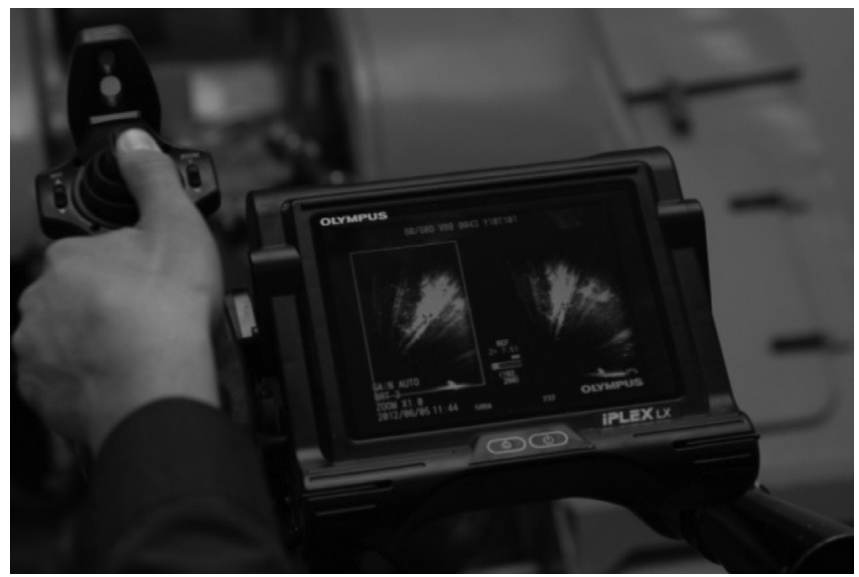

Rys. 5. Wideoskop Iplex LX podczas badań lufy. Źródło: Opracowanie własne

Fig. 5. The videoendoscope Iplex LX during an inspection of barrel. Reference: private elaboration

Aparatura zastosowana podczas badań luf armat morskich dokonanych w Pracowni Broni Rakietowej i Artylerii AMW (PBRiA AMW) posiada niewielką masę i zasilanie akumulatorowe. Kompletny system, łącznie z akcesoriami i walizką, można przenosić na kolejne miejsca pracy, w prawie każdych trudnych warunkach.

Model wideoskopu IPLEX LX spełnia wymagania środowiskowe uznawane przez międzynarodowe normy wojskowe (MILSTD-810G /MIL-STD-461F), w tym próby w deszczu i wietrze, wilgotności, mgle solnej, piasku i pyle, oblodzeniu/ marznącym deszczu oraz w atmosferze zagrażającej wybuchem - zgodność z normami IP55. Są one też wytrzymałe na drgania lub upuszczenie $z$ wysokości do 1,2 m. Końcówki sondy wideoskopu IPLEX LX wytrzymują temperatury do $100{ }^{\circ} \mathrm{C}$. Odporne na zgniecenia sondy wideoskopów posiadają oplot zewnętrzny ze wzmocnionego wolframu, zapewniający odporność na ścieranie. Jeśli zaistnieje ryzyko przegrzania się sondy, czujnik wysokiej temperatury wysyła ostrzeżenie za pomocą sygnału dźwiękowego i wyświetlenia wskaźnika ostrzegającego. Wytrzymałość sondy oraz jej elastyczność pozwala na inspekcje nawet w trudnych okrętowych warunkach i niebezpiecznym otoczeniu. Wykorzystywana aparatura pomiarowa waży $2,7 \mathrm{~kg}$.

Podstawą wykonania badań wizualnych - endoskopowych jest właściwe przygotowanie powierzchni wewnętrznej luf armat morskich. Przygotowanie polega na usunięciu zanieczyszczeń, smarów, produktów korozji itp. w taki sposób, aby nie została naruszona pierwotna postać tej powierzchni lub przynajmniej nie zostały zamaskowane (zakryte) takie wady powierzchniowe, które powinny być wykryte w czasie badań. W zestaw stanowiska badawczego, rysunek 5. wchodzi urządzenie wykonujące wiele z wymaganych czynności w sposób automatyczny.

Inna, niebezpieczna wada luf armat morskich powstaje w wyniku współdziałania miedzianego pierścienia wiodącego pocisku ze ściankami lufy i gazami prochowymi, w wyniku czego na powierzchni przewodu osadza się miedź. W przewodzie lufy miedź osadza się nierównomiernie, tworząc następujące tzw. strefy zamiedzenia.

\section{Badania wizualne luf $23 \mathrm{~mm}$ armat ZU-23-2MR}

W celu potwierdzenia przydatności stanowiska do szybkiej diagnostyki i ustalenia przydatności uzbrojenia i sprzętu wojskowego do dalszej eksploatacji - wykonywanej pod- 
czas jego obsługi - dokonano badań $23 \mathrm{~mm}$ morskiej armaty ZU-23-2MR. Stanowisko badawcze do badań luf armat morskich wyposażono w urządzenie diagnostyczne do oceny ich stanu technicznego za pomocą wideoskopu IPLEX LX (rys. 6.).

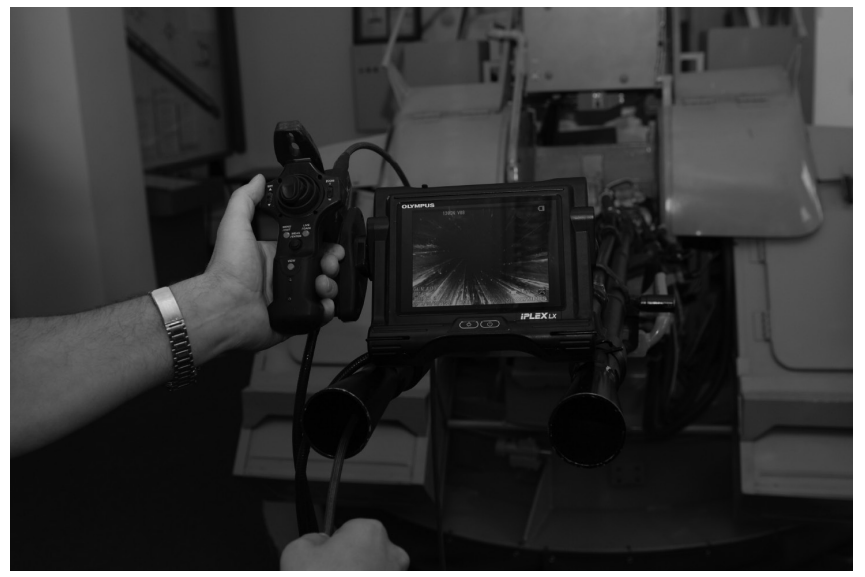

Rys. 6. Stanowisko badawcze $23 \mathrm{~mm}$ luf ZU-23-2MR w AMW. Źródło: Opracowanie własne

Fig. 6. The inspection setup of $23 \mathrm{~mm}$ barrels of ZU-23-2MR in the PNA. Reference: private elaboration

W warunkach codziennej eksploatacji armat morskich dominującym zjawiskiem jest wilgoć - powietrze o dużej zawartości wody i soli. Dlatego też, uszkodzenia powierzchni metali (luf) prowadzą do ich nieodwracalnej degradacji co skutkuje tym, że nawet przy właściwej eksploatacji i stosowaniu zalecanych środków konserwacji - powstawanie ognisk rdzy będzie się nasilało wraz ze wzrostem czasu eksploatacji, a taka nieinwazyjna metoda diagnostyki luf artyleryjskich może pozwolić na szybkie i dokładne określenie aktualnego stanu technicznego UiSW - bez jego demontażu.

Dzięki wyświetlaczowi o niskiej odbijalności monitor z funkcją Daylight-View do pracy przy silnym nasłonecznieniu oferuje wyraźne, żywe obrazy nawet przy silnym nasłonecznieniu.

Model wideoskopu IPLEX LX pozytywnie przeszedł testy środowiskowe uznawane przez międzynarodowe normy wojskowe (MILSTD-810G /MIL-STD-461F), w tym próby w deszczu i wietrze, dużej wilgotności, mgle solnej, piasku i pyle, oblodzeniu/marznącym deszczu oraz $w$ atmosferze zagrażającej wybuchem. Są one też wytrzymałe na drgania lub upuszczenie z wysokości do 1,2 m. Końcówki sondy wideoskopu IPLEX LX wytrzymują temperatury do $100{ }^{\circ} \mathrm{C}$. Jeśli zaistnieje ryzyko przegrzania się sondy, czujnik wysokiej temperatury wysyła ostrzeżenie za pomocą sygnału dźwiękowego i wyświetla wskaźnik ostrzegający. Odporne na zgniecenia sondy videoskopów posiadają oplot zewnętrzny ze wzmocnionego wolframu, zapewniający odporność na ścieranie. Wytrzymałość sondy oraz jej elastyczność pozwala na inspekcje nawet w trudnych warunkach i niebezpiecznym otoczeniu występujących na okrętach Marynarki Wojennej RP.

Analiza stanu wnętrza lufy badanej armaty wskazuje na występowanie licznych ognisk korozji. Są to defekty wskazujące na utlenianie się wewnętrznej powierzchni lufy, zwłaszcza w miejscach, w których wystąpiły uszkodzenia mechaniczne podczas eksploatacji bojowej.

W analizowanym przykładzie zlokalizowano i rozpoznano co najmniej trzy ogniska korozji, charakteryzujące różne stany degradacji powierzchni wewnętrznej lufy, tj. korozję punktową, plamową i wżerową.

Lufy armat pracują w warunkach określanych jako środowisko gazowe (żrące) oraz w warunkach gwałtownych zmian ciśnienia i temperatury. Stąd, występujące naprężenia i zmęczenie techniczne materiału prowadzą utleniania się powierzchni, a następnie pękaniai łuszczenia się warstw skorodowanych.

W konsekwencji prowadzi to do powstawania uszkodzeń mechanicznych i strukturalnych wewnętrznej powierzchni lufy.

Zastosowana aparatura i nieinwazyjna metoda diagnostyczna luf artyleryjskich, może pozwolić na szybkie i dokładne ustalenie przydatności uzbrojenia i sprzętu wojskowego do dalszej eksploatacji. Szczególnie dużą przydatność należy przewidywać w miejscach trudno dostępnych, $\mathrm{np}$. w przypadku, gdy demontaż elementu armaty jest utrudniony i czasochłonny.

Badania nieniszczące można wykonać w celu określenia aktualnego stanu technicznego lub wykrycia przyczyn awarii lub uszkodzenia sprzętu, jak również w celu wyeliminowania tych przyczyn, dla zapewnienia bezpiecznej eksploatacji uzbrojenia.

Badania endoskopowe UISW, a w tym luf armat morskich, zaleca się wykonywać w następujących sytuacjach:

- przy bieżącej ocenie stanu technicznego, w razie konieczności przedłużenia okresu międzyremontowego itp.;

- w czasie realizacji przeglądów profilaktycznych (co najmniej raz w roku), które powinna obejmować niezbędny zakres i chronologię prowadzenia przeglądów przestrzeni wewnętrznych, umożliwiających wykrycie defektów poszczególnych elementów i układów funkcjonalnych.
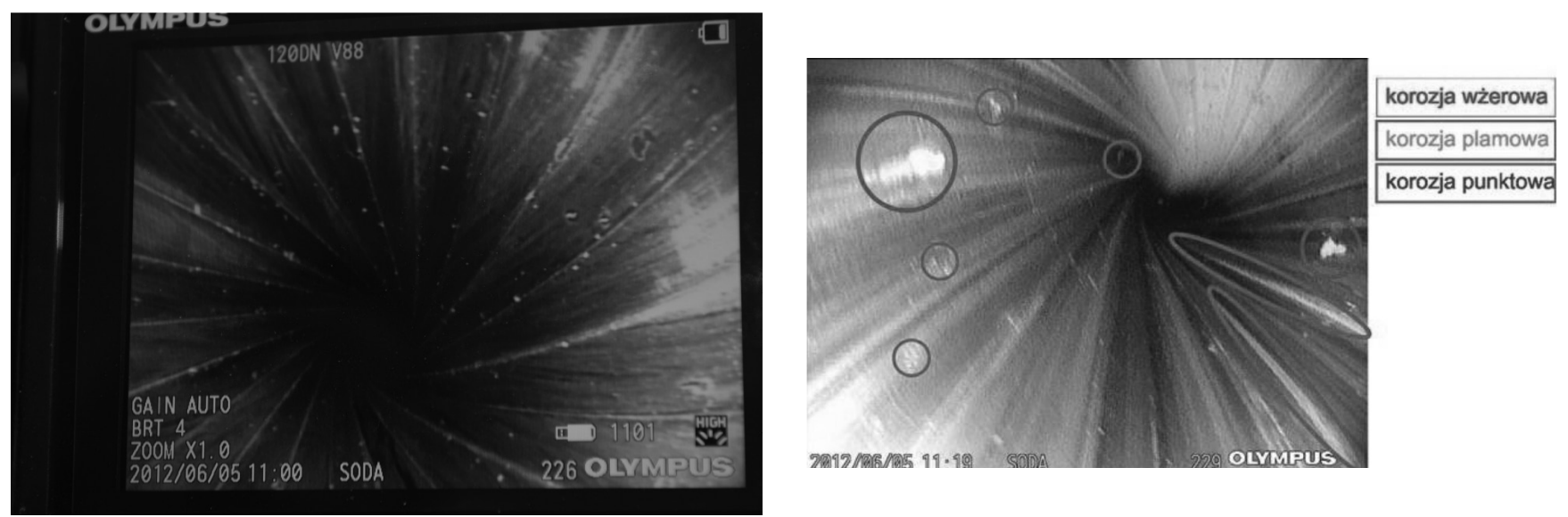

Rys. 7. Analiza stanu wewnętrznej powierzchni lufy. Źródło: Opracowanie własne

Fig. 7. The analysis of state of inner surface of barrel. Reference: private elaboration 
Podczas badań endoskopowych uzbrojenia okrętowego i sprzętu wojskowego szczególną uwagę należy zwracać na: - pęknięcia, rysy oraz ubytki materiału;

- intensywność procesów zanieczyszczenia i zużycia poszczególnych elementów;

- występowanie lokalnych ogniw korozji oraz erozji po- wierzchniowej.

Urządzenia i endoskopowe (wizualne) techniki diagnostyczne są szczególnie przydatne w sytuacjach, gdy sprawdzenie stanu technicznego uzbrojenia odbywa się w miejscach trudnodostępnych, a sam proces sprawdzenia jest utrudniony i czasochłonny.

\section{Wnioski}

Badania nieniszczące - wizualne luf artyleryjskich stanowią źródło podstawowych informacji niezbędnych dla podjęcia decyzji dotyczących badanych luf artyleryjskich lub decyzji diagnostycznych (opinia techniczna), związanych z ich dalszą eksploatacją.

W referacie zaprezentowano niektóre istotne elementy oceny stanu technicznego luf artyleryjskich, która może mieć formę opinii bądź ekspertyzy technicznej. Opinia techniczna to ocena stanu luf artyleryjskich wystawiona jest na podstawie badań wizualnych i dostępnej dokumentacji luf artyleryjskich. Natomiast ekspertyza techniczna to ocena stanu luf artyleryjskich poparta badaniami i wyliczeniami wytrzymałościowymi.

Zapewnienie szybkiego i poprawnego rozwoju diagnostyki technicznej luf artyleryjskich stawia też określone wymagania przed systemem edukacji w Siłach Zbrojnych RP, w którym zagadnienie kształcenia młodych kadr dla potrzeb diagnostyki jest już wyraźnie sprecyzowane i oczekuje na szybkie wdrożenia. Jakże często podejmowane nowe kierunki badań, w tym i wybrane problemy diagnostyki zasygnalizowane, w tym artykule stanowią o randze tej dyscypliny naukowej. Ich przedstawienie pobudza niejednokrotnie do intensywnych badań, znacznie ułatwiających możliwości nowych dokonań, na które oczekuje praktyka okrętowa.

Podczas opracowywania prognoz diagnostycznych uzbrojenia artyleryjskiego należy uwzględnić dane o prawidłowości rozwoju procesów kontrolowanych i ich uwarunkowaniach rozwojowych, a także możliwych, dodatkowych czynnikach wpływających na ich przebieg. W niniejszym artykule autorzy zaprezentowali jedną z metod diagnostyki luf artyleryjskich, którą z powodzeniem można zastosować do oceny stanu technicznego pozostałego uzbrojenia morskiego. Zastosowanie nowoczesnych metod i technik badawczych w procesie eksploatacji uzbrojenia artyleryjskiego, nie zastępuje diagnostycznego myślenia, lecz przeciwnie, zwiększa wymagania, wymuszając dodatkowe złożone analizy, związane z oceną możliwości ich użycia.

Zgodnie z promowanym modelem kształcenia oficera w AMW, uczelnia powinna uczyć słuchaczy aktywności, samodzielnego myślenia, krytycznego podejścia do różnorodnych informacji, wartościowania i hierarchizowania wydarzeń, indywidualnego oraz grupowego rozwiązywania problemów. Podobne założenia zostały przyjęte przy badaniu możliwości wdrożenia nowoczesnych technologii czyszczenia i konserwacji uzbrojenia okrętowego, jako procesu wspomagającego kształcenie w ramach przedmiotów uzbrojeniowych.

Wybór tej metody poszukiwania wad, powinien nastąpić zdaniem autorów, po wcześniejszym ustaleniu, przyczyn wystąpienia niesprawności lub uszkodzenia uzbrojenia artyleryjskiego i jakiego typu to mogą być defekty.

Badania wizualne luf artyleryjskich pozwalają na szybką i wnikliwą ocenę ich stanu technicznego bez konieczności częściowego demontażu w/w sprzętu. Zapewnienie szybkiego i poprawnego rozwoju diagnostyki technicznej luf artyleryjskich będących przedmiotem diagnostyki technicznej jest wyraźnie sprecyzowane i oczekuje na szybkie wdrożenia.

Jakże często są podejmowane nowe kierunki badań, w tym i wybrane problemy diagnostyki zasygnalizowane, w tym artykule stanowią o randze dyscypliny naukowej. Ich przedstawienie pobudza niejednokrotnie do intensywnych badań, znacznie ułatwiających możliwości nowych dokonań, na które oczekuje dobra praktyka uzbrojeniowa.

\section{Literatura}

[1] Chmieliński M., Jurczak W., Kubisiak Sz., Lipnicki M., Pojawa B.: Laboratoria badawcze NDT $\mathrm{w}$ procesie zapewnienia bezpieczeństwa wyrobów techniki wojskowej. VIII Międzynarodowa Konferencja „Laboratoria badawcze, systemy jakości w Unii Europejskiej”, Łagów/ Brandenburgia $11 \div 14$ czerwca 2014 r.

[2] Chmieliński M., Gołyga M., Kubisiak Sz.: Diagnostyka stanu technicznego luf artyleryjskich przy wykorzystaniu wideoskopów VI Międzynarodowa Konferencja Naukowo-Techniczna „Technologie morskie dla obronności i bezpieczeństwa" Gdańsk 24-26 czerwca 2014 r.

[3] Chmieliński M., Kubisiak Sz.: Nowoczesne badania nieniszczące luf armat morskich podstawą bezpieczeństwa eksploatacji techniki wojskowej. Przegląd Spawalnictwa 2014, R. 86, nr 11.

[4] Chmieliński M., Hoppe J., Milewski S., Możliwości wykorzystania nowoczesnego sprzętu diagnostycznego w procesie obsługiwania uzbrojenia okrętowego. Materiały I Międzynarodowej Konferencji Naukowo - Technicznej IBM AMW i OBR CTM „Technika i uzbrojenie morskie" NATCon 2007, Gdynia 24-26.10.2007.
[5] Chmieliński M., Milewski S., Pojawa B.: Nowoczesne metody badań diagnostycznych uzbrojenia okrętowego i sprzętu wojskowego. Zeszyty Naukowe AMW 172B. Publikacje z zakresu „Kierowania ogniem systemów obrony powietrznej przeciwlotniczej", Gdynia 2008r.

[6] Praca zbiorowa pod redakcją Lipnicki M.: Badania metodami nieniszczącymi, Poradnik dla inspektorów, PRS/Koli, Gdańsk 1991

[7] Poddubny W. Korozja broni i amunicji. Warszawa 1961.

[8] Norma Obronna NO-06-A01 1:2003 Fazy cyklu życia techniki wojskowej.

[9] Norma Obronna NO-06-A011:2003 Fazy procesu życia techniki wojskowej. Military engineering products lifecycle stages. Decyzja $\mathrm{Nr}$ 29/MON z dnia 10 lutego 2003 r. (Dz. Urz. MON z 2003 r. Nr 2, poz. 13).

[10] Norma Obronna NO-10-A009:2005 Broń artyleryjska - Rodzaje i podstawowe cechy - Terminologia.

[11] PN-EN 1330-2 Badania nieniszczące - Terminologia - Terminy wspólne dla badań nieniszczących.

[12] http://www.olympus-ims.com/pl 